\title{
DEVELOPMENT OF ECOSYSTEM SERVICE OPPORTUNITIES IN THE NEMUNAS DELTA IN THE CONTEXT OF GLOBAL CLIMATE CHANGE
}

\author{
Vytautas Pilipavičius ${ }^{1}$, *Jan Žukovskis ${ }^{2}$ \\ ${ }^{1}$ Vytautas Magnus University, Lithuania \\ ${ }^{2}$ Klaipeda University, Lithuania \\ *Corresponding author's email: jan.zukovskis@vdu.lt
}

\begin{abstract}
The second half of the $20^{\text {th }}$ century brought to light the consequences of human activity, when Humanity was confronted with demiurgical complexes and realized that the planet Earth was not only nature, but a complex system that today could no longer be operated by traditional methods and logic. While until the middle of the $20^{\text {th }}$ century man used natural resources only to meet his needs, the $21^{\text {st }}$ century poses new challenges for mankind to manage the consequences of human activities and to use them rationally and sustainably.

The paper presents a study aimed at assessing the potential of ecosystem services development in the Nemunas Delta and anticipating their development directions. As a result of the research, the possible development directions of the Elderships were presented. It was done in two scenarios.

The research was carried out in six municipality subdivisions (elderships) of the Nemunas Delta area in the framework of the Lithuanian Science Council project 'Interaction of ecosystem services and human activities in the context of climate change'. Preparation of this paper was supported by funding from European Social Fund (project No 09.3.3-LMT-K-712-01-0178) under the grant agreement with the Research Council of Lithuania (LMTLT).
\end{abstract}

Key words: climate change, development, ecosystem services, elderships.

\section{Introduction}

Rapid economic development in the $20^{\text {th }}$ century has shown that a Man, believing in the absolute power of scientific and technical progress, has become the master of nature, able to transform nature in its own way so that it can meet its ever-increasing needs. There is a widespread belief that increasing material production is the only true measure of society's progress and prosperity. By the end of the 1960's, environmental pollution had reached a level where it was no longer possible to devote no attention to the problem.

Managing the consequences of human activities, through the rational and sustainable use of natural resources while ensuring the repeatability of living conditions for future generations, poses new challenges for the $21^{\text {st }}$ century community.

The European Union has linked the development to a smart, sustainable and inclusive growth (EU 2020 strategy), taking into account the consequences and projections of global change.

The Lithuanian Parliament approved the National Climate Change Management Policy Strategy for 2013-2050 (National Climate Change ..., 2012). This strategy foresees the need to formulate and implement Lithuania's climate change management policy mitigation and adaptation, defining short-term (by 2020), medium-term (by 2030 and 2040) and longterm (by 2050) goals and objectives.

The Lithuanian Science Council project 'Interaction of Ecosystem Services and Human Activities in the Context of Climate Change' aimed to highlight the directions of ecosystem services development in the Nemunas Delta in the context of global climate change.
The aim of the study is to evaluate the development possibilities of ecosystem services in the Nemunas Delta and to predict the directions of development.

Objectives:

- To provide methodological provisions for the study of the development of ecosystem services;

- To conduct empirical research on the development of ecosystem services in the Nemunas Delta;

- To summarize the data of empirical research and to envisage directions of development.

For the research, scientific literature and documentary sources have been analyzed, and the content analysis and empirical research methods have been used.

\section{Materials and Methods}

The turn of the $20^{\text {th }}$ and $21^{\text {st }}$ centuries, with the acceleration of scientific and technological advances and new socio-economic opportunities and prospects, is characterized by radical changes (Melnikas, 2002). Change can be perceived in two ways: change is one of the common causes of human development and progress; change is an essential result of global development and progress. In other words, change is determined by the existence of human beings in the evolution of human life - natural processes and change initiated by organized human activities that shape the progress of human life - artificial processes (Grigaliūnienè, 2000).

Ecosystem services are opportunities provided by the ecosystem as natural artefacts that become resources in the human development process.

Today, the complexity of the interaction between the worlds of nature and human activity is being 


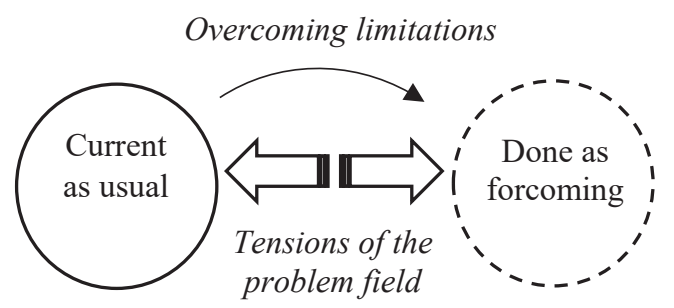

Figure 1. Developments in Overcoming Limitations.

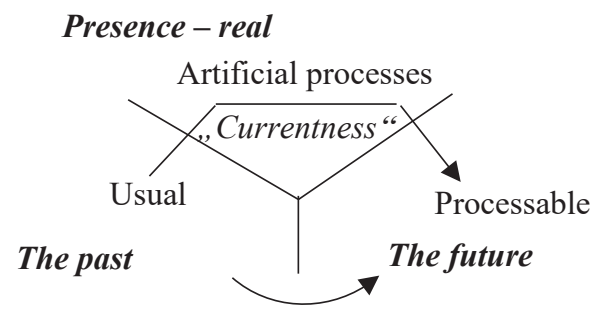

Natural processes

Figure 2. Tensions of the problem field (Щедровицкий, 2019).

actualized in terms of global climate change. The source of change - development, as the initiator of change, manifests itself in overcoming the limitations of traditional thinking, Figure 1.

Problem field tensions are stability interruption situations arising in the process of change that create preconditions for development and require new situation definiteness in the past-future-present interaction, Figure 2.

Today, in the context of global change access (Schwab, 2018), we can associate development with

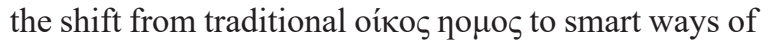
organizing oíkos $\lambda$ oros, capturing the tensions of the problematic field in three dimensions of time: being as acting reality in relation to the past (what is past); you are in touch with the present (what is real); you are in touch with the future (what is to come).

Development is based on a complex, systemic nature, providing reproductive, developmental, and investment functions (Мескон et al., 2004).

Reproductive functions associated with problematization of the 'being' in the present-past tension, ensuring continuous functioning in the short term, focused on the repetition of lifestyle conditions.

Improvement functions with problematization of the 'being' in the tensions of the present and the future, in order to progress in the medium term with a view to improving the quality of life.

Investment functions - with the problematization of the 'being' as done in the tension of the future and as usual as in the past, in the long-term perspective of strategic development focused on shaping the future lifestyle.

Integrated development of ecosystem services is directly related to the concept of sustainable development (A Short History of ..., 2015), as an instrument of sustainable development, responsible social behaviour, ensuring the connection between investment and territorial development, solving problems of care change and shaping future social clutches of cultural lifestyles and other contemporary global issues that reflect a new tradition.

Methodology of Empirical Research

An empirical study has been carried out to analyse the feasibility of developing ecosystem services in the Nemunas delta in the context of global climate change.

- Assessment of potential problems of climate change consequences in the Nemunas delta area;

- Analysis of the status and trends of the Nemunas Delta ecosystem services;

- Analysis of relevance and foresight of climate change management directions in the Nemunas Delta.

The questionnaire was based on the International Climate Change Commission (IPCC) projections on the major consequences of climate change (Конттантинов, 2018), research conducted in Lithuania (Climate Change ..., 2017), Common International Systematic Classification of Ecosystem Services (CICES) and the European Commission's Covenant of Mayors for Climate and Energy (Climate Change and Adaptation ..., 2017) documents.

The study included an assessment of the state of ecosystems and their development trends, as well as a comparative analysis. The evaluation was performed on a scale from 0 to 3 . The results of the study are presented in graphs. 
Hierarchy of potential problems of climate change consequences

\begin{tabular}{|c|l|c|c|c|c|c|c|}
\hline \multirow{2}{*}{ No. } & \multicolumn{2}{|c|}{ Climate change phenomena } & \multicolumn{3}{|c|}{ Hierarchy $(1-$ most important, 8 - least important) } \\
\cline { 3 - 7 } & & Farmers & $\begin{array}{c}\text { Tourist } \\
\text { farmsteads }\end{array}$ & Communities & Experts & Sum & Average \\
\hline 1 & $\begin{array}{l}\text { Increasing recurrence of dangerous natural } \\
\text { phenomena }\end{array}$ & 3 & 1 & 1 & 1 & 6 & $\mathbf{1}$ \\
\hline 2 & Increase in average annual air temperature & 5 & 2 & 3 & 4 & 14 & $\mathbf{4}$ \\
\hline 3 & Increasing heat wave repeatability & 1 & 6 & 4 & 2 & 13 & $\mathbf{3}$ \\
\hline 4 & $\begin{array}{l}\text { Increase in frequency of squalistic wind } \\
\text { (hurricanes) amplification }\end{array}$ & 6 & 6 & 5 & 1 & 18 & $\mathbf{5}$ \\
\hline 5 & Average increase in rainfall & 2 & 4 & 2 & 2 & 10 & $\mathbf{2}$ \\
\hline 6 & $\begin{array}{l}\text { Declining and earlier onset of spring } \\
\text { flooding in rivers }\end{array}$ & 7 & 7 & 8 & 5 & 27 & $\mathbf{7}$ \\
\hline 7 & $\begin{array}{l}\text { Increasing frequency of low tides and } \\
\text { heavy rainfall in summer }\end{array}$ & 4 & 5 & 4 & 1 & 14 & $\mathbf{4}$ \\
\hline 8 & $\begin{array}{l}\text { Rising sea level in the Baltic Sea increases } \\
\text { the frequency of salt water flow into the } \\
\text { Curonian Lagoon }\end{array}$ & 8 & 3 & 6 & 5 & 22 & $\mathbf{6}$ \\
\hline 9 & Absence of snow, ice and frost & 6 & 8 & 7 & 6 & 27 & $\mathbf{7}$ \\
\hline 10 & Desertification (natural area crawl) & 7 & 3 & 5 & 7 & 22 & $\mathbf{6}$ \\
\hline 11 & Change of habitats of dangerous pathogens & 6 & 2 & 3 & 3 & 14 & $\mathbf{4}$ \\
\hline
\end{tabular}

\section{Results and Discussion}

A questionnaire survey was used to conduct the study. Respondents were selected as the target groups whose activities are directly related to the territory of the Nemunas Delta. They are farmers (23), owners of tourism and rural homesteads (14) and heads of rural community organizations (11). Experts (6 people) also participated in the survey: Head of Silute (Šilute) Life Protection Inspectorate; Head of the Nemunas Delta Regional park administration; Director of Silute Forest Enterprise; Head of JSC 'Silutes polderiai';
Head of the Department of Rural Affairs and Planning and Development of Silute District municipality.

Table 1 presents a hierarchical analysis of potential climate change impacts in the Nemunas Delta.

The data in the table show different views of farmers, farmsteads and experts. This is determined by the nature of the respondents' activities and their importance. According to general respondents, the most problematic would be the increase of recurrence of dangerous natural phenomena, the average increase of precipitation and the increase of heat wave repeatability.
Provisioning services

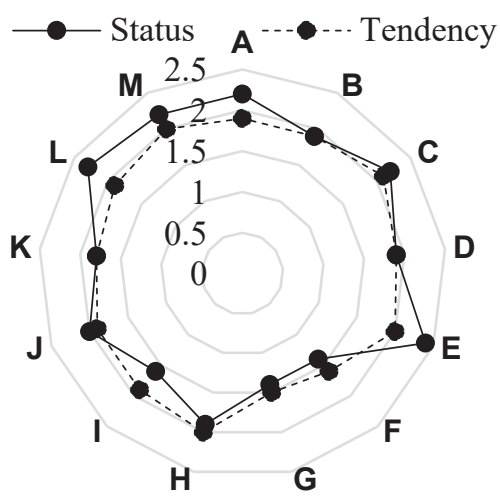

Types of provisioning services

A Crops, fruits and other cultivated plants for food

B Fungal, algae or bacterial resources used as material

C Plant resources used as an energy source

D Aquaculture - animals raised for food

E Domestic animals are raised for food

F Animal resources used as material

$\mathrm{G}$ Animal resources used to produce energy

$\mathrm{H}$ Materials derived from wild plants for use or processing (eg herbs)

I Resources of wild plants, fungi and algae used for energy production

J Wild animals (terrestrial and aquatic) and their products for human consumption (eg fish)

$\mathrm{K}$ Drinking water from surface water sources

L Surface water for purposes other than drinking

M Drinking water from groundwater sources

Figure 3. Assessment of the status and trends of provisioning services. 


\section{Regulatory services}

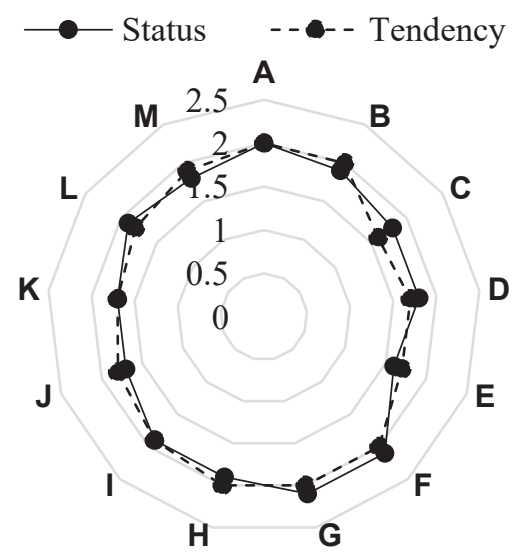

Types of regulatory services

A Biological purification using microorganisms, activated sludge, plants and animals

B Waste and wastewater filtration, retention is done by microorganisms, algae, plants and animals

C Soil erosion control and prevention

D Water flow regulation, flood risk reduction

E Wind/storm protection

F Fire protection

G Provision of wild plant and animal habitats

$\mathrm{H}$ Control of pests and invasive species

I Disease control

J Soil formation, maintenance of soil fertility

$\mathrm{K}$ Maintenance of soil organic matter balance

L Regulation of the chemical status of freshwater bodies

Figure 4. Assessment of the status and trends of regulatory services.

\section{Types of cultural services}

A Nature's properties related to health - active use

B Nature's properties related to health, nature's observation passive use

C Natural qualities that allow for scientific research or the accumulation of traditional ecological knowledge

D Living-nature qualities that provide opportunities for learning/ nurturing

E Nature features as a source of heritage that allow identification with the history or culture of the place of origin

F Living-nature qualities that give aesthetic experience

G Nature elements with symbolic meaning (used as national or other symbols)

$\mathrm{H}$ Nature elements of religious, spiritual significance (objects of spiritual and religious importance)

I Nature elements related to nature knowledge (objects in nature, used in film production, book writing, etc.)

$\mathrm{J} \quad$ Nature features, objects in nature that should be protected

$\mathrm{K}$ Natural qualities that have a legacy value for future

\section{Cultural services}
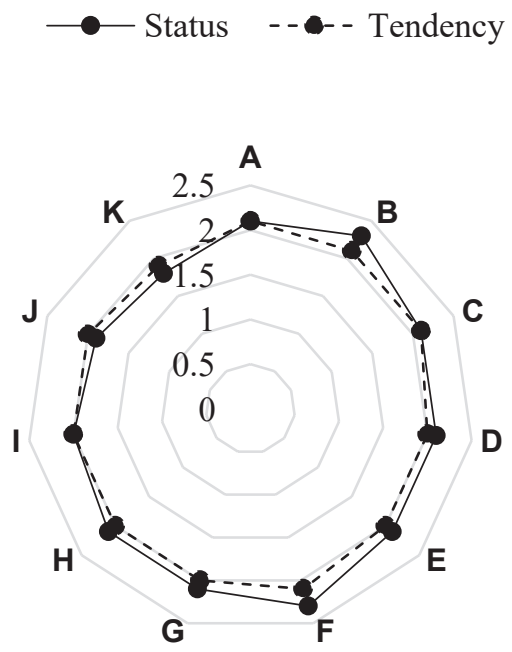

Figure 5. Evaluation of the status and trends of cultural services.

The study of the status and trends of the Nemunas Delta ecosystem services is based on an assessment of respondents' attitudes towards the status and trends of ecosystem provision, regulation, and cultural services (General International Classification of Ecosystem Services). The scale of ecosystem services was rated as good, 3, medium 2 and bad 1; trends: improving 3 ; neutral -2 ; getting worse -1 .

Respondents views of the state and trends of ecosystem provision, regulation, and cultural services are presented in Figures 3, 4, and 5.

The figures summarize the results of the evaluation of ecosystem services of all respondents. However, some respondents differed in their assessment.

Farmers, tourism homesteads and community organizations ranked the types of welfare services best as 'domesticated livestock', 'drinking water from groundwater sources'. The worst-case status was mentioned by the respondents in question as 'animal resources used as material' (eg. wool) and 'animal resources used for energy production' (eg. plowing horses). 'Plant resources used as a source of energy' (eg willow biofuels, straw) and 'crops, fruits and other cultivated plants for food' were the best rated by experts. Worst of all are the 'plant, mushroom and algae resources used for energy production'.

Farmers, tourists and community organizations were the most likely to appreciate the status of regulatory services as 'wildlife and animal habitat protection' and 'fire protection'. Worst of all are 'water flow regulation, flood risk reduction' and 'soil 
erosion control and prevention'. Experts ranked the type of regulatory service as 'biological purification using microorganisms, activated sludge, plants and animals', and worst 'wind/storm protection'.

The condition of cultural services was evaluated similarly by all respondents: best of all - 'nature features that enable health, nature monitoring passive use' and 'life features that provide aesthetic experience'; worst of all, 'natural features that have a heritage value (objects that future generations could use or enjoy)' and 'natural properties as a source of heritage to identify with the history or culture of the place of origin'.

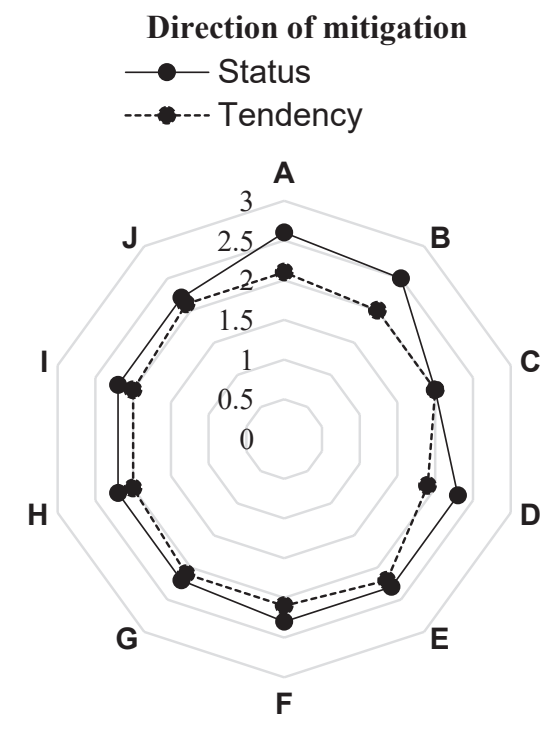

The status of relevance of the measures envisaged in the European Commission document and trends in the development of ecosystem services in the area of the Nemunas Delta were analyzed for the evaluation of the directions of management of the consequences of climate change. Scale of rating, conditions: relevant 3 ; neither yes/no - 2; not relevant -1 , trend: expected 3 ; doubtful - 2; unforeseen -1 .

The sixth, seventh and eighth figures summarize the assessment of the relevance status and prognostic tendencies of the management measures of the focus group survey on the consequences of climate change in the Nemunas Delta.

Figure 6. Assessing the effects of climate change on mitigation management.
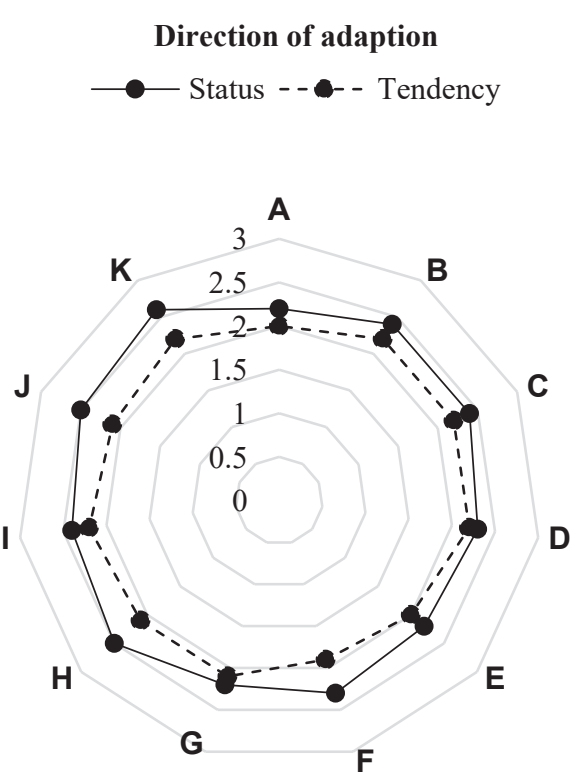

\section{Mitigation measures}

A To develop new and improve existing state road infrastructure, or part thereof, which consists of paved roads

B Renewal and development of transport infrastructure and improvement of the environment and safety

C To promote the collection and use of biogas for energy production and to reduce methane emissions

D Implement waste management system management and waste incineration projects

E Encourage companies to increase their use of renewable energy sources by co-financing projects

F To promote the co-generation of low-power biofuels

$\mathrm{G}$ Forest management, fire protection, prevention of natural disasters, diseases and pests, conservation and breeding of forest genetic resources

$\mathrm{H}$ To promote the cultivation of new economically valuable, productive, bio-resistant forests on private land

I Encourage the acquisition of machinery and equipment for the production of wood-based biofuels

J Purchase / modernization of municipal waste
Figure 7. Assessing the effects of climate change on management of adaption.

\section{Direction of adaption}

A Implement projects to strengthen environmental monitoring and control

B Implement agri-environment programs

C To investigate the agrochemical properties of soil

D Implementation of management measures for the Curonian Lagoon and the Lower Nemunas River

E Implement biodiversity protection projects

F To implement investments that enhance the resilience and environmental value of forest ecosystems

$\mathrm{G}$ Restoring forestry potential and introducing prevention measures against fires, natural disasters, pests and diseases and climate change-related events

$\mathrm{H}$ To carry out maintenance and repair of forest road and drainage system equipment, to install and maintain forest recreational, environmental and scientific objects

I Implement water resource management and protection, water supply and wastewater management projects

$\mathrm{J}$ Implement projects to improve the status of surface water bodies

Implement flood risk management projects 


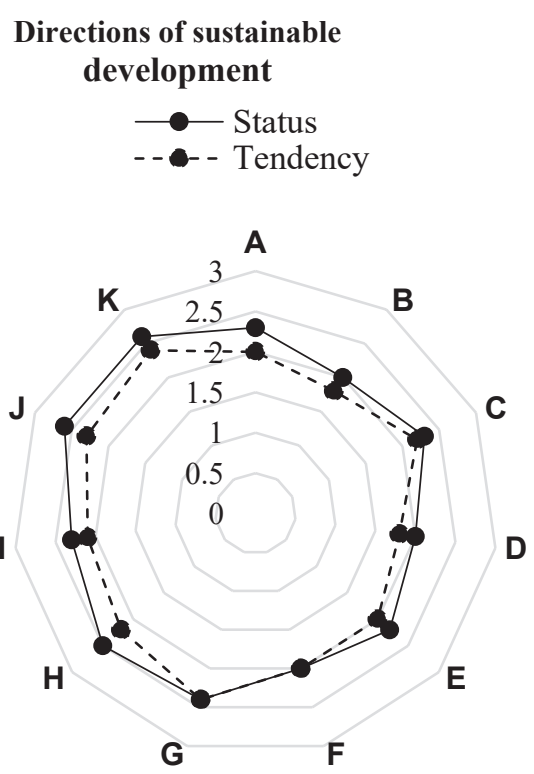

\section{Measures for sustainable development}

A The development of the economy does not depend on the development of achievements, but on what is required in the future

B Business is not about profit, but about economic, social and environmental well-being

C Increasing soil productivity by biological and technological means rather than chemical

D Protein food extraction from beef animal production to other protein food extraction sources

E Separation of water supply systems for food and technological operations

F Transition from machinery using diesel, gasoline to machinery using other sources of energy

G Efficient use of thermal energy in industrial and residential buildings

$\mathrm{H} \quad$ Extraction of energy from renewable sources

I Complete sorting of industrial and household waste

$\mathrm{J}$ Educating the younger generation in the reality of the future

K Personal behaviour and behaviour for future generation prosperity

Fgure 8. Assessing the consequences of climate change for sustainable development.

Summarized survey data of respondents indicate that:

- Public road infrastructure, or part of it consisting of asphalt roads, 'implementing waste management system management and waste incineration projects' and 'upgrading and developing transport infrastructure' and 'improving environmental protection and safety'. At the very least, 'capture and use of biogas to reduce methane emissions for energy production' and 'promote the acquisition of machinery and equipment for the production of wood-based biofuels';

- The most relevant in the direction of adaptation are 'water resource management and protection' and 'water supply and wastewater management', 'improvement of surface water bodies' and 'flood risk management projects'. Less relevant are 'implementation of environmental monitoring and control projects' and 'implementation of forestry potential and prevention measures against fires, natural disasters, pests and diseases';

- Respondents attribute the most urgent measures to managing the consequences of climate change in the direction of sustainable development - 'energy from renewable sources', 'educating the younger generation by changing the way education is organized in the future' and 'personal behaviour and behaviour for future generations'. At the very least, 'business is not about profit, but about economic and social well-being' and 'protein- based food transition from livestock farming to other sources of protein-based food'.

- Overall, the direction of managing the consequences of climate change is more or less relevant, but implementation trends in all directions are questionable in most areas.

Summary of Research Results

Today, in the context of global change, uncertainty and complexity are shaping a new developmental biology, similar in complexity to biological systems, which prevents the development of ecosystem services from being controlled by conventional means. This requires a review of traditional competencies and the shaping of current competencies for future well-being, reflecting outstanding competencies, without diminishing the future potential of human well-being.

Development opportunities could be described in two scenarios - waiting for the future and acting for the future.

Based on the chronos (time) tops (Figure 2), three directions of ecosystem services development in the Nemunas Delta can be distinguished:

- The development of ecosystem services in the short term, mitigating or reducing the scale of climate change problems in the present, as a consequence of past socio-economic and socio-cultural assumptions;

- Developing ecosystem services in the medium term, adapting to the potential consequences of climate change, and shaping the future socio-cultural fabric of community life that guarantees well-being of population; 
- The long-term development of ecosystem services is based on sustainable development, where each sector, private or public or nongovernmental, pursuing different goals serves the common interest, forming a new, different picture for the future.

Modern business has gone beyond the economic sample alone. This poses new challenges for innovation, entrepreneurship, competitiveness, sustainability and systematisation. Therefore, one must refrain from strictly focusing on one type of resource - finance, and introducing a series of different operational management systems that combine social, cultural, economic, intellectual, ecological and similar factors.

\section{Conclusions}

1. The development of ecosystem services in terms of global change has to do with: heritage management, mitigating the effects of climate change in the present-past relationship; intergenerational coherence management, adapting to the potential consequences of climate change in the presentfuture relationship; with sustainable development forming a new socio-cultural and socio-economic nexus in the future-past relationship, capable of synchronizing with the pace of change.
2. Empirical research has shown that respondents look at global climate change quite disconnectedly as if they were not concerned. They associate the development of ecosystem services in the Nemunas Delta, largely with mitigation of the potential consequences of climate change, with little adaptation to climate change and with little to no sustainable development. This suggests that, while the climate change management measures envisaged by the European Commission are positive, the commitment to them in developing ecosystem services in the Nemunas Delta is poor.

3. The change in natural and artificial processes indicates that we are on the verge of global change, turbulence, as old performance management systems stagnate and new ones are still in a state of birth. Thus, not only the value-added production process but also the process of change of performance management tools becomes the central axis.

\section{Acknowledgements}

Preparation of this paper was supported by funding from European Social Fund (project No 09.3.3-LMT-K-712-01-0178) under grant agreement with the Research Council of Lithuania (LMTLT).

\section{References}

Stofleth, D. (2015). A Short History of Sustainable of Development. Retrieved September 10, 2019, from http:// rethinkingprosperity.org/a-short-history-of-sustainable-development/.

Common International Classification of Ecosystem Services (2013). European Environment Agency (EEA) Retrieved July 10, 2019, from https://cices.eu/.

Grigaliūnienè, S. (2000). Professional management. Kaunas: VDU.

Climate change mitigation and adaptation climate change guidelines for municipalities (2017). Vilnius, Association of Lithuanian Municipalities.

Communication from the Commission - Europe 2020 A strategy for smart, sustainable and inclusive growth (2010). Retrieved September 10, 2019, from http://ukmin.lrv.lt/uploads/ukmin/documents/files/ Strategija\%202020\%20LT.pdf.

National Climate Change Policy Strategy (2012). SEIMAS OF THE REPUBLIC OF LITHUANIA. Retrieved August 8, 2019, from https://e seimas.lrs.lt/portal/legalAct/lt/TAP/71f17ca2081f1 1e8802fc9918087744d? jfwid=-fa58gt41z.

Константинов, П.И. (2018). Изменение климата. Реальность, предубеждение, негативные последствия. (Climate change. Reality, prejudice, negative consequences). Retrieved August 10, 2019, from https:// drive.google.com/drive/folders/1KP4sRaIUNDYhBXb4GZBQm2pepX3AzKPs?ogsrc=32. (in Russian).

Melnikas, B. (2002). Transformations. Vilnius: Vaga.

Schwab, K. (2018). Management of the Fourth Industrial Revolution. Vilnius: Vaga.

Мескон, М., Альберт, М., \& Хедоури, Ф. (2004). Основы управления. (Basics of Management). Moscow: Delo. (in Russian).

Щедровицкий, П.Г. (1993). Экономические формы организации бизнеса и современные предпринимательские стратегии. (Economic forms of business organization and modern entrepreneurial strategies). Retrieved November 10, 2019, from https://shchedrovitskiy.com/formi-hozyaistva-ipredprinima.../. (in Russian). 